\title{
INFLUENCE OF PERSONALITY TRAITS ON CYBERLOAFING IN THE SERVICE SECTOR OF PAKISTAN
}

\author{
Sanaullah Abro', Nazar Hussain², Saifullah Memon³ ${ }^{3}$ and Manzoor Ali Brohi ${ }^{4}$
}

\begin{abstract}
The main purpose of this study was to analyze the relationship between the Big Five Personality Model and Cyberloafing. Results have demonstrated that the elements of the five-factor personality model are positively related to cyberloafing, and some factors are inversely related to cyberloafing. The five major elements of the five-factor personality model are Agreeableness, Openness to Experience, Neuroticism, Consciousness and Extraversion. Two of the five factors, i.e., Agreeableness and Consciousness, are inversely related to cyberloafing whereas Extraversion, Openness to Experience, and Neuroticism are linked positively. Furthermore, results suggest that Agreeableness and consciousness do not have a significant impact on cyberloafing. An individual with these traits is found to be more of a workaholic, because of their belief in commitment and work. This study findings have some valid implications for organizational managers to gain insight into employees ' personalities and their cyberloafing behaviour.
\end{abstract}

Keywords: Neuroticism; Extraversion; Openness to Experience; Agreeableness; Conscientiousness; Cyberloafing.

\section{INTRODUCTION}

Global environmental dynamics have brought about changes within various fields due to the advent of the internet. The advancements on the internet have helped companies and organizations in a variety of ways to boost their business by cutting their costs, increasing efficiency, shortening periods of production, and find more economical ways of marketing (Anandarajan, Simmers, \& Igbaria, 2000). It has been analyzed that the personal use of the

\footnotetext{
${ }^{1}$ Department of Public Administration SALU Khairpur, Pakistan. Email: sanaullahniaz@gmail.com

${ }^{2}$ Department of Public Administration SALU Khairpur, Pakistan. Email: nazar.hussain@salu.edu.pk

${ }^{3}$ Department of Information technology QUEST Nawabshah, Pakistan. Email: memonsaifullah@quest.edu.pk

${ }^{4}$ Department of Management Sciences, City campus BUITEMS Quetta, Pakistan. Email: manzoor.ali@buitms.edu.pk
} 
internet is reasonable according to some ideologies (Muhl, 2003). On the one hand, the internet has assisted every individual in doing their work efficiently and effectively, whereas, on the other hand, the likelihood of an individual doing personal work such as online shopping and engaging with social media connections during work hours has considerably increased. Cyberloafing is defined as cyber-slacking which means doing less work than one can, due to spending needless hours surfing the internet for personal use during work hours (Lim \& Vivien, 2002; Lim \& Teo, 2005).

There are various reasons for cyberloafing that engage employees at work. Numerous studies have been conducted in order to look for previous circumstances with this kind of behaviour. These studies have found that employees are engaged in cyberloafing because of factors such as stress in the workplace that may include role conflict, role ambiguity, role overload and others. It has been noticed that individuals in the workplace who face these kinds of problems move towards cyberloafing in order to overcome stress (Sawitri \& Runing, 2012). This study is focused on the past studies of cyberloafing by combining the five-factor personality model to identify the extent to which of these factors contribute to cyberloafing.

The study of Arshad et al. (2016) has suggested further work on cyberloafing by considering other factors which impact employees' behaviour in an organization. Furthermore, the study of Huma et al. (2017) has explained the basis of the theory of interpersonal behaviour (TIB) and has further suggested that to get better inferences we need to be working on different theories and models through Pakistan's perspective. Research has suggested focusing on individual and situation-related variables that are supposed to predict the personal interests of the employees of private organizations in this competitive environment (Jamaluddin et al., 2015). Additionally, Baturay \& Toker (2015) have indicated to work on cyberloafing behaviours, more specifically in private sector organizations.

Advancements in technology have transformed organizations to conduct business in the markets in various new ways (Tapia, 2006). The internet has boosted the communication processes of organizations (Messarra, Karkoulian \& McCarthy, 2011) and has become a necessity of every individual. The internet has enhanced the knowledge of each individual which in turn is supporting companies to a great extent in making decisions (Seymour \& Nadasen, 2007; Cheng et al., 2020). The internet has a variety of benefits for businesses such as good performance, minimization of the cost, and reduced period of production (Henle \& Blanchard, 2008; Sawitri, 2012). Besides all these positive aspects of the internet, there is a 
dark side to the internet, which may also be called a double-edged sword (Kim, Del Carmen Triana, Chung \& Oh, 2015; Li, Sarathy, Zhang \& Luo, 2014).

The advent of the internet has provided a variety of ways to laze during working hours (Wagner, Barnes, Lim \& Ferris, 2012). Cyberloafing has engaged employees during work hours in personal activities such as browsing the internet on non-work-related stuff, using social media accounts, sending personal emails, downloading personal stuff, and shopping online (Sai'd Ibrahim Al-Shuaibi, Subramaniam \& Shamsudin, 2014). All, these behaviours harm the organization, and these come under the umbrella of cyberloafing (Sai'd Ibrahim AlShuaibi et al., 2014). According to Ugrin, Pearson \& Odom (2008), cyberloafing can be defined as cyber slouching, cyber slacking, online loafing and/or junk computing. Cyberloafing is defined as "any voluntary act of employees" accessing the company's internet connection during the time of work to explore three or more websites on the internet for personal purposes and to send and receive personal emails is a misuse of the internet of the organization (Lim, 2002). Therefore, cyberloafing is a type of counterproductive behaviour at work which is known as deviant work behaviour (Rana \& Punia, 2014). This is the use of company resources and time at work that is unproductive for the organization (Lim, 2002). There is not any policy to restrict the use of the internet during office hours, and cyberloafing is considered independent of the policies of an organization. Cyberloafing has two facets to it, positive and negative. The positive aspect of cyberloafing is that the boredom, stress, and fatigue of the employees is released (Ozler \& Polat, 2012). Additionally, studies have found that an employee's cognitive resources may be recovered by increasing the employee's wellbeing, which will lead to job satisfaction and creativity while browsing personal websites (Askew, 2012; Ozler \& Polat, 2012). Although cyberloafing has its positive effects, its negative effects directly impact organizations and businesses with issues such as data security \& hacking, network overload, spyware, and viruses because of visits to unauthorized websites and downloads (Kim et al., 2015). There are legal liabilities, copyrights claims and cases of harassment because of cyberloafing traced from internet protocol (IP) addresses (Restubog et al., 2011).

\section{STATEMENT OF THE PROBLEM}

The globalization of technology has a myriad of effects; with negative impacts on employees that are engaged in leisurely activities during work hours. In this context, studies relating the issues pertaining to organizational loafing, employees' loafing behaviour and organizational 
performance have been very meagre. Despite the fact that literature on organizational performance and behaviour has been vastly studied and is always a centre of attention for researchers, concentration on loafing behaviour has been neglected. Moreover, due to the diverse organizational cultures and employees, it is essential to research the concealed facts regarding diversity in employees' personality traits and its relationship with cyberloafing behaviour.

\section{RESEARCH OBJECTIVES}

This research has specific objectives which are as follows:

- To determine how cyberloafing and the Five-Factor Personality Model is conceptualized in the literature.

- To determine the relationship between cyberloafing and the Five-factor Personality Model amongst the employees in Pakistan.

- To determine which of the five factors of the "Personality model" are involved in cyberloafing.

- To determine the traits of employees inclined towards cyberloafing.

- To add value in organizations with results and recommendations for further research in the future on other factors.

\section{RESEARCH QUESTIONS}

- How cyberloafing and Five-Factor Personality Model is conceptualized in literature?

- What is the relationship between cyberloafing and the Five-factor Model of Personality among the employees of Pakistan?

- Which of the Five-Factor Personality model's elements are engaged in cyberloafing activities?

- What are the recommendations that can be made for future research?

\section{SIGNIFICANCE OF THE STUDY}

It has been demonstrated in this research to identify employees' engagement in cyberloafing considering the Five-Factor Personality Model. The study signifies to understand the amount of profitability is impacted because of cyberloafing in businesses during work hours. This will help organizations to choose employees with specific traits that do not coincide with traits of those who cyberloaf. Also, this outcome will help increase a business's profitability and by paying close attention to the components that impact their businesses due to cyberloafing, 
corporate heads can make sure such activities are not carried out and rather accommodate their employees in ways that will not hinder their business and company's reputation.

Pakistani context studies related to cyberloafing are very limited, therefore, this study will also explore the antecedents of cyberloafing in Pakistan. This investigation extends past examinations on cyberloafing by combining the different factors in a single model to check the degree to which they add to cyberloafing. This study examines the degree to which employees' abuse of the web involves significant expenses to associations and influences workers' efficiency. It is important to comprehend what propels people to participate in this conduct with the goal that successful hierarchical mediation projects and approaches might be produced and actualized to expel or restrict its event (Lim \& Vivien, 2002).

\section{THEORETICAL FRAMEWORK}

Five proposed paths have been developed to explore in this study. These paths include the link of the 5 big personality traits to cyberloafing. The evidence from the previous studies have been identified for each link and it has been discussed in the proposed research model of this study.

Figure 1. Research Model

Independent Variable

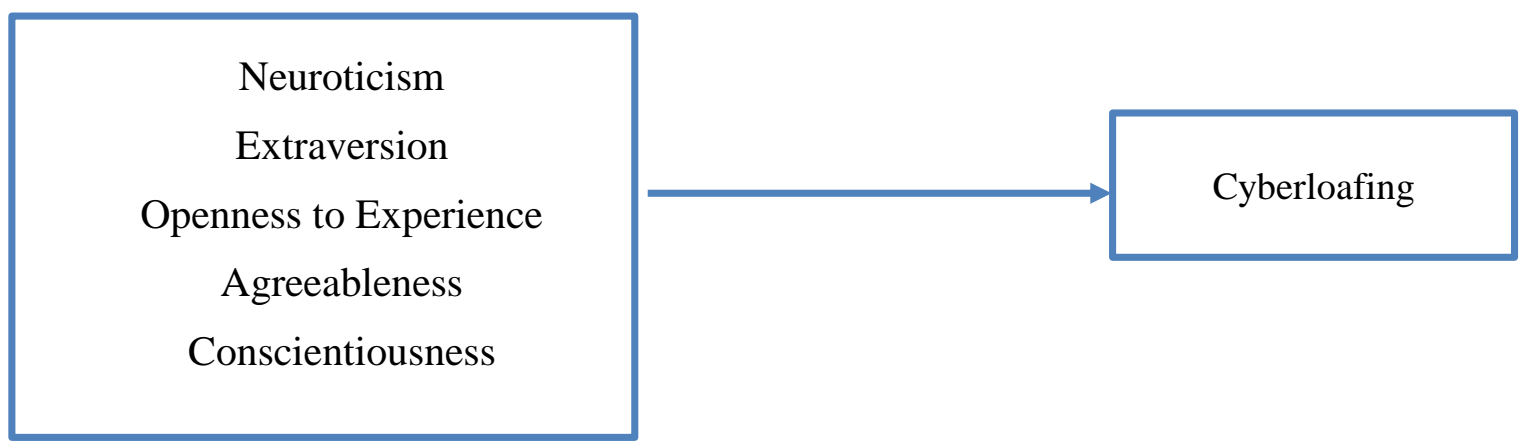

Source: Author's proposed Model

\section{LITERATURE REVIEW}

Advancements in technology have changed the way organizations conduct business in the markets (Tapia, 2006). The internet has boosted communication and processes of organizations (Messarra, Karkoulian \& McCarthy, 2011), and has become a necessity for each individual in 
work and life (Griffiths, 2010). The Internet has also enhanced the level of knowledge in each individual that helps businesses to a great extent in making decisions in an organizational setup (Seymour \& Nadasen, 2007) and provides a variety of benefits for an individual employee to have good performance, minimize the cost, and reduce the cycle time of production (Henle \& Blanchard, 2008; Sawitri, 2012). Besides all these positive aspects of interest, there is a dark side to the internet, and it is also called a double-edged sword (Kim, Del Carmen Triana, Chung \& Oh, 2015); (Li, Sarathy, Zhang \& Luo, 2014).

\section{Neuroticism \& Cyberloafing}

The Five-Factor Model is a collection of identity traits in five wide areas: Extraversion (Surgency), Agreeableness, Consciousness, Emotional Stability (Neuroticism) and Openness to Experience (Intellect) (McCrae \& John, 2016). Neuroticism is emphatically identified with authoritative counterproductive work practices (DeShong et al., 2015). It is important that to a certain degree the five-factor model of identity makes practical neuroticism rather than enthusiastic solidness, which is basically the opposite end of neuroticism. The five measurements that rise reliably in exact investigations crosswise over societies (McCrae \& John, 2016) are reliability, extraversion, pleasantness, receptiveness to involvement, and neuroticism.

However, the neuroticism execution relationship is the second most grounded among attributes of the Big Five (Barrick, Mount, \& Judge, 2001), the two features appear to be most proper for various parts of execution (DeYoung et al., 2007). For instance, people with specific characteristics like high good faith may be compensated by associations and consequently report larger amounts of employment fulfilment, while properties like neuroticism may incline people toward bringing down levels of occupation fulfilment (Steel, Schmidt, \& Schultz, 2008). It has been proposed that outgoing individuals utilize interpersonal organization locales as another and extra method for communicating their propensities (Ross et al., 2009).

Strangely, it ought to be noticed that meta-investigative surveys have indicated conscientiousness to be particularly identified with work execution and Neuroticism to be adversely identified with work execution (Salgado, 2002). In one examination in light of this model, it was discovered that addictive propensities towards informal organization destinations were emphatically identified with Neuroticism, Extroversion, and error in work (Wilson, Fornasier, \& White, 2010). 
Specialists contended that identity, particularly, the big five assumes a critical part in deciding why a few people tarry more than others. Research has demonstrated that people who are high on scruples have a tendency to take part in low level loafing practices (Colbert, Mount, Harte, Witt, \& Barrick, 2004). People who score low in enthusiastic security tend to encounter adverse feelings, for example, stress, outrage, or sorrow (McCrae, \& Costa, 2021). Their endless stressing, shakiness, hesitance, and low-pressure resistance make them inclined to mental clutter (McCrae, \& Costa, 2008; McCrae, \& John, 1992). Another side says that individuals getting a high score in enthusiastic security have a tendency to be quiet, casual, and calm (McCrae, \& John, 1992). Be that as it may, it does not imply that they are high in positive psychological well-being, however rather, low in negative emotional well-being (McCrae, \& John, 1992).

H1: There is a positive relationship and significant impact of Neuroticism on employees' cyberloafing behaviour.

\section{Extraversion \& Cyberloafing}

There has been debate over the definition of Extraversion among the researchers over the period of time. According to (Judge et al., 2013; McCrae \& John, 2016) an extrovert is a friendly, sociable, assertive, and active individual. Extraverts mostly enjoy working and these kinds of people are found to be energetic at work by working with a diverse group of people (Judge et al., 2013). Whereas introverts are those who are less social and more reserved because of their inner fear (Judge et al., 2013). It should be considered under importance that the last point of each spectrum is not polar opposite for one another, taking the example of an individual who has a low score in extraversion should not consider as unfriendly, besides all the people with a high score in extraversion can be friendly with others (McCrae \& John, 2016).

It has been noted that extroverts are more sociable, positive, and dominant over others in a social setting (Watson, \& Clark, 1997). Individuals who get a high score in extraversion are found to be more active outgoing, social, and outing with high values in warm and close interpersonal relationships (Watson, \& Clark, 1997). It has been noticed that extroverts tend to be gregarious, sociable, and try to attract the environment by stimulation (Eysenck, 1967), these individuals are using the internet as a source of developing relationships and socializing and often seek consciousness relations. A study (e.g., Kraut et al. 2002) has conceded that individuals with a high score in the extraversion often abuse the use of the internet as a platform 
of socialization. Wyatt and Phillips (2005) have found that individuals with these traits of extraversion have abused the use of the internet and use more time on the internet socializing with other people and spend time on activities that are not related to work that has decreased the productivity of their work. After analyzing all these studies, it is very much clear that people with a high score in extraversion are passing time leisurely during office hours as compared to those who have a low score in extraversion.

\section{H2: Extraversion has a positive relationship and significant impact on employee's} cyberloafing behaviour.

\section{Openness to Experience \& Cyberloafing}

These individuals have a set of the defined principle of appreciation, divergent thinking, and try to find a variety (McCrae \& Costa, 2021). One with a high score in openness to experience has been found as an intellectual individual with more curiosity and trying to explore new things around them (Judge et al. 2002; McCrae \& John, 2016). Contradictorily, an individual with a low score in openness to experience is found to handling tasks conventionally, having the narrow interest of exploring new things, and resist change by exploring and trying new things in their lives (McCrae, \& Costa, 2008). A person who is getting a high score on openness to experience is found to be creative, flexible, unconventional, and curious (McCrae, 1996). Individuals who have this kind of trait are defined as people who are willing to experience different and new activities that have importance in the organizational work activities (Hough, \& Furnham, 2002). Work performance study has explained that openness to experience is associated positively with new learning processes/activities and proficiency (Barrick et al. 2001).

Openness to experience is found to be positively related to motivation in accomplishing their targeted goals without any supervision (Judge, \& Iles, 2002). According to (Mount et al., 2006) behaviour of an individual with a low score has deviant behaviour. Further, researchers have revealed that the outcomes were valid for both relational and undertaking based CPBs. It is legitimately sensible to expect that individuals who score high on openness to experience will invest less energy in cyberloafing and would rather spend their time learning new things and work towards business-related objectives.

H3: Openness to Experience has a positive relationship and significant impact on the employee's cyberloafing behaviour. 


\section{Agreeableness \& Cyberloafing}

Agreeableness is a factor that measures the degree of altruism, cooperation, and individual trust (McCrae \& John, 2016). An individual who is having a low score in agreeableness is considered as self-centered and hostile. According to (Digman \& Takemoto-Chock, 1981) agreeableness can be explained as "Friendly Compliance versus Hostile Noncompliance". (McCrae, \& Costa, 2008) says that they believe agreeableness needs to be connected to happiness as an individual who has a high score in agreeableness is more motivated to achieve targeted goals (Judge, Heller, \& Mount, 2002).

H4: There is an inverse relationship of agreeableness trait on employee's cyberloafing behaviour.

\section{Conscientiousness \& Cyberloafing}

The sign of honest identity is restraint which is normally reflected in a requirement for accomplishment, request, and constancy (Costa et al. 1991). As per Ones and Viswesvaran, very upright people demonstrate more noteworthy efficiency than less faithful people on the grounds that: (a) they invest more energy in undertakings they are allotted; (b) they set objectives self-sufficiently and endure in tailing them; and (c) they stay away from counterproductive practices (Ones \& Viswesvaran 1996). Further, principled identities are naturally inspired to accomplish, perform at an abnormal state, and take activities to enhance their work execution. In accordance with this thinking, examining generational abnormality recommends that good faith is adversely identified with CPBs (Salgado, 2002). Further, Sackett \& DeVore (2001) revealed that scruples are the steadiest indicator of such practices. Consequently, as conscientiousness mirrors a natural inspiration to enhance execution wherever conceivable, we expect that honest individuals would invest less energy in cyberloafing contrasted with their partners. That is, people who report high scores on conscientiousness would cease their cyberloafing practices.

H5: There is an inverse relationship of Conscientiousness on the employee's cyberloafing behaviour.

\section{Cyberloafing}

Besides all variables mentioned earlier, it is important to notice other correlates of cyberloafing that are worth noticing. Considering the personality of an individual as positive affects (Lim \& Chen, 2009), impulsivity (Davis, Flett, \& Besser, 2002), control (Blanchard \& Henle, 2008), 
extraversion (Jia, 2008), and agreeableness (Krishnan et al., 2010) which says that locus has been identified as an antecedent of cyberloafing.

Cyberloafing has two different outcomes; (Blanchard \& Henle, 2008; Lim \& Teo, 2005; Ugrin \& Pearson, 2013) either they will be harmful to the organization, or they could not be such harmful. These behaviours are actually abusive. (Blanchard \& Henle, 2008; Lim \& Teo, 2005) told that this abusive cyberloafing sort of behaviour can also be beneficial for the organizations, and even they can make habitual some of the individuals to be regular to certain limited behaviours which they actually are not doing willingly.

In one of the previous studies, two researchers Ugrin \& Pearson (2013), experimentally asked participants to rank the various cyberloafing activities, they used the scale from 0 to 100 and found very unusual responses. According to the responses, the personal mail was considered to be the very least considered behaviour of cyberloafing with the mean of (30.8). The authors used several other behaviours for which they identified the respective mean score to summarize the most and least influencing factor of cyberloafing before the individuals. According to the respondents, pornography was considered the most influencing behaviour of cyberloafing with the mean of 96.8 ranked out of 100 .

Whereas Lim and Chen (2012) found that cyberloafing behaviours are such as watching the news on TV or online news channels or website, searching irrelevant things from websites not related to work, following sports websites is also considered as less influencing, but a cyberloafing behaviour. Whereas, chatting, downloading irrelevant materials from blogs and unreliable sources, and playing online games are considered as extreme cyberloafing behaviours. The least influencing behaviours were called less abusive cyberloafing behaviours, and the most influencing behaviours are called strong abusive cyberloafing behaviours (Blanchard \& Henle, 2008; Ugrin \& Pearson, 2013).

Blau, Yang and Ward-Cook (2004), identified three different influences of cyberloafing in their experimental study, and they named these three influences as:

1. Interactive cyberloafing

2. Browsing-related cyberloafing

3. Non- work-related e-mail cyberloafing (Blau et al., 2006)

Later, researchers also identified various items as well as measured all three influences (Blau et al., 2006). Various researchers also believe that cyberloafing is also a predictor element of work stressors, organizational justice, and sleep disorders (Henle \& Blanchard, 2008; Lim, 2002; Wagner, Barnes, Lim \& Ferris, 2012). 


\section{RESEARCH METHODOLOGY}

\section{Research Design}

In this research study, a deductive approach is used because the nature of the study is quantitative, and a descriptive analysis of all variables is included in the study framework. The type of data is cross-sectional, and the positivism research philosophy has been used as this type of research is hypothesis-testing research that has a significant base of support for theoretical evidence.

\section{Population Frame}

Middle-level employees (Middle managers) who work in the private sector in the metropolitan cities of Pakistan including Karachi, Hyderabad, Lahore, Islamabad, Peshawar, Faisalabad, Multan, Quetta, and Rawalpindi are selected for this study to analyze the impact of their personality traits on cyberloafing behaviour at their workplaces.

\section{Sample Size and Sampling Method}

A sample of 222 respondents was studied. To collect diverse responses for this research, a random sampling method was used. Around 250 people were invited to participate in this search, whereas we received 222 responses therefore the response rate was $88.8 \%$.

\section{Measurement Instrument}

A self-explanatory questionnaire has been used to measure the impact, significance, and relationship of the study. The questionnaire includes the following 6 scales:

- The neuroticism scale contains 5 items to compute the results.

- The Extraversion scale is another trait of the big five personality model. It has a total of 5 items of measurement to the scale. It has been adopted from (Michael A. Sage, 2015).

- The third scale has been used as Openness to Experience which has a total of 5 items to measure the impact. The scale has been adapted from (Michael A. Sage, 2015).

- The agreeableness scale has 5 items to measure it. The items of this scale have been adopted from (Michael A. Sage, 2015).

- Conscientiousness has also included 5 items to measure the scale of impact. These items have been adopted from (Michael A. Sage, 2015).

- Cyberloafing is the dependent variable used in this study. It has a total of 7 items to measure the results. The scale has been adapted from (Michael A. Sage, 2015). 


\section{Data Collection Technique}

For this research, an online survey questionnaire was used to collect data from respondents. A Google form was generated with specific items. This Google form was shared with the targeted audience in Karachi and Islamabad.

\section{Data Analysis Technique}

Statistical tests were conducted using SPSS version 25 to analyze the data. Regression Analysis was used to analyze data in order to get meaningful inferences. The correlation test was carried out to measure the inter-relationship between the constructs of the research model.

\section{RESULTS}

\section{Instrument Reliability Tests}

To measure the reliability of the instrument (questions and items present in the questionnaire) used for the data collection, Cronbach's Alpha and Composite Reliability tests were run using SPSS (v.16). In order to measure the internal consistency of items, Cronbach's Alpha and Composite Reliability tests were run using SPSS (v.16). The result of the tests shows that (see table 5.1) Cronbach's Alpha value of all items, is 0.922 (92.2\%), the result of the Composite Reliability test also shows the high internal consistency among the items.

Table 1. Reliability Test

\begin{tabular}{lcc}
\hline & Reliability Statistics \\
\hline Scale & Cronbach's Alpha & N of Items \\
Neuroticism & 0.920 & 5 \\
Extraversion & 0.920 & 5 \\
Openness to Experience & 0.919 & 5 \\
Agreeableness & 0.919 & 5 \\
Conscientiousness & 0.921 & 5 \\
Cyberloafing & 0.918 & 7 \\
Total & 0.922 & 32 \\
\hline
\end{tabular}

Source: Data Analysis of this Study

\section{Frequencies and Demographics}

The tables below illustrate the frequencies and demographics regarding Age, Gender, and Education indicate the frequency of respondents, initially based on age factors. 
Table 2. Age of Respondents

\begin{tabular}{lcccc}
\multicolumn{5}{c}{ Age } \\
\hline & Frequency & Per cent & Valid Percent & Cumulative Percent \\
\hline 20-25 Years & 109 & 49.1 & 49.1 & 49.1 \\
26-31 Years & 68 & 30.6 & 30.6 & 79.7 \\
32 and above years & 45 & 20.3 & 20.3 & 100.0 \\
Total & 222 & 100.0 & 100.0 & \\
\hline
\end{tabular}

Source: Data Analysis of this Study

Table 2 shows the results of the age of the respondents of the study. It shows that there was a total of 222 participants, among them 109 participants which are almost half of the sample of study (49.1\%) are of the age group 20 to 25 years of age. Similarly, 68 participants were of the age of 26 to 31 and 45 participants were 32 years of age and above.

Table 3. Respondent's Gender

\section{Gender}

\begin{tabular}{cccccc}
\hline & & Frequency & Percent & Valid Percent & Cumulative Percent \\
\hline Valid & Male & 164 & 73.9 & 73.9 & 73.9 \\
& Female & 58 & 26.1 & 26.1 & 100.0 \\
& Total & 222 & 100.0 & 100.0 & \\
\hline
\end{tabular}

Source: Data Analysis of this Study

As per table 3 above, all 222 questionnaires were filled by 164 male and 58 female respondents. The percentage of male respondents is $73.9 \%$ and the female percentage of participants is $26.1 \%$.

Table 4. Respondents' Qualification

\begin{tabular}{cccccc}
\hline \multicolumn{5}{c}{ Education } \\
\hline Valid & BS & Frequency & Percent & Valid Percent & Cumulative Percent \\
& MS & 96 & 49.5 & 49.5 & 49.5 \\
& PhD & 16 & 43.2 & 43.2 & 92.8 \\
& Total & 222 & 100.0 & 7.2 & 100.0 \\
\hline
\end{tabular}

Source: Data Analysis of this Study

The educational status of respondents is shown in the table given in the appendix. As per table 4, 110 respondents have a BS degree, 96 have an MS degree and 16 respondents have a $\mathrm{PhD}$ degree. 
Table 5. Correlation

\section{Correlation Matrix}

\section{Mean SD CL Neuroticism Extraversion Openness Agreeableness Conscientiousness to \\ Experience}

\begin{tabular}{|c|c|c|c|c|c|c|c|c|}
\hline Cyberloafing & 11.84 & 2.29 & 1 & & & & & \\
\hline Neuroticism & 22.71 & 5.39 & $.720^{* *}$ & 1 & & & & \\
\hline Extraversion & 16.07 & 4.22 & $.833^{* *}$ & $.630^{* *}$ & 1 & & & \\
\hline $\begin{array}{l}\text { Openness to } \\
\text { Experience }\end{array}$ & 14.73 & 2.70 & $.955^{* *}$ & $.721^{* *}$ & $.719^{* *}$ & 1 & & \\
\hline Agreeableness & 15.81 & 3.4 & $.768^{* *}$ & $.752^{* *}$ & $.502^{* *}$ & $.859^{* *}$ & 1 & \\
\hline Conscientiousness & 13.20 & 2.8 & $.636^{* *}$ & $.675^{* *}$ & $.861^{* *}$ & $.591^{* *}$ & $.404^{* *}$ & 1 \\
\hline
\end{tabular}

Source: Data Analysis of this Study

The correlation table 5. shows that Cyberloafing (DV) is positively correlated by $72 \%, 83.3 \%$, $95.5 \%, 76.8 \%$ and $63.6 \%$ (at 0.05 level of significance) with IV1 to IV5 (Neuroticism, Extraversion, OTE, Agreeableness, Consciousness) respectively.

\section{Regression Analysis}

In the model fit, the R-squared value is 0.979 , suggesting that about $97.9 \%$ of the variation in the dependent variable can be explained by variations in the independent variables. The remaining $2.1 \%$ is explained by error terms. The ANOVA table has an overall significance of the model, and the F value is also more than 4 which show the significance of the study.

Table 6. Regression Analysis

\begin{tabular}{|c|c|c|c|c|c|c|c|}
\hline \multicolumn{8}{|c|}{ Regression Analysis } \\
\hline & \multicolumn{2}{|c|}{$\begin{array}{l}\text { Unstandardized } \\
\text { Coefficients }\end{array}$} & \multirow{2}{*}{$\begin{array}{c}\text { Standardized } \\
\text { Coefficients } \\
\text { Beta }\end{array}$} & \multirow[b]{2}{*}{$\mathrm{T}$} & \multirow[b]{2}{*}{ Sig. } & \multicolumn{2}{|c|}{$\begin{array}{l}95 \% \text { Confidence Interval } \\
\text { for B }\end{array}$} \\
\hline Model & B & $\begin{array}{l}\text { Std. } \\
\text { Error }\end{array}$ & & & & $\begin{array}{l}\text { Lower } \\
\text { Bound }\end{array}$ & $\begin{array}{l}\text { Upper } \\
\text { Bound }\end{array}$ \\
\hline (Constant) & -.544 & .308 & & -1.767 & .079 & -1.150 & .063 \\
\hline Neuroticism & .276 & .032 & .165 & 8.514 & .000 & .212 & .340 \\
\hline Extraversion & .897 & .040 & .516 & 22.155 & .000 & .817 & .977 \\
\hline $\begin{array}{l}\text { Openness } \\
\text { Experience }\end{array}$ & 1.142 & .036 & .815 & 31.956 & .000 & 1.071 & 1.212 \\
\hline Agreeableness & -.236 & .031 & -.181 & -7.495 & .000 & -.298 & -.174 \\
\hline Conscientiousness & -.641 & .044 & -.327 & -14.604 & .000 & -.728 & -.555 \\
\hline
\end{tabular}

a. Dependent Variable: Cyberloafing DV 
1. Neuroticism: On average, the increase in Neuroticism by one unit will increase Cyberloafing DV by 0.165 (16.5\%) when all other variables are kept constant. The positive sign of the coefficient shows a direct relationship. It is significant in its parameter and proves the expected hypotheses.

2. Extraversion: On average, the increase in Extraversion by one unit will increase Cyberloafing DV by $0.516(51.6 \%)$ by keeping all other variables constant. The positive sign of the coefficient shows a direct relationship. It is significant in its parameter and proves the expected hypotheses.

3. Openness to experience (OTE): On the average increase in Openness to experience by one unit will increase Cyberloafing by 0.815 (81.5\%) when all other variables are kept constant. The positive sign of the coefficient shows a direct relationship. It is significant in its parameter and proves the expected hypotheses.

4. Agreeableness: On the average increase in Agreeableness by one unit will decrease Cyberloafing DV by 0.181 (18.1\%) when all other variables are kept constant. The negative sign of the coefficient shows an inverse relationship. But it is significant in its parameter and proves the expected hypotheses.

5. Consciousness: On the average increase in Consciousness by one unit will decrease cyberloafing DV by 0.327 (32.7\%) when all other variables are kept constant. The negative sign of the coefficient shows an inverse relationship. But it is significant in its parameter and proves the expected hypotheses.

\section{DISCUSSION}

In this study, the big 5 factors of personality traits have been tested on cyberloafing. The results of the study are significant and strongly correlated with each other (see table 5 and 6 correlation, and coefficient). The agreeableness and conscientiousness traits have an inverse relation with cyberloafing. Whereas neuroticism, extraversion, and people with a trait of openness to experience have a positive correlation with cyberloafing (see the correlation, table 5). It means that various personality traits have an impact on cyberloafing, the impact has been identified as two ways, few people react normally, and inverse and others have positive but according to all the respondents, cyberloafing has a significant relationship with the personality traits. 


\section{CONCLUSION}

This research has investigated the relationship of individual personality traits and their relationship with cyberloafing behaviour at the workplace. People who have the personality trait of agreeableness and conscientiousness react inverse to cyberloafing, they believe that cyberloafing will not be a positive influencing factor, but it is actually found to be inverse. Whereas all other three traits of personality have a significant and positive relationship with cyberloafing. This study defends the traits as per their actions in cyberloafing.

Cyberloafing is divided into 2 groups of personality traits, those which are encouraging it; and which are discouraging it. The items such as sports, news, social media, non-work-related websites, entertainment, and personal emails are understood as the causes of cyberloafing. In previous studies, it has been noticed that conscientiousness and agreeableness are related to low cyberloafing activities. Those who got a high score in the study with openness to experience, extraversion, and neuroticism have related to cyberloafing.

\section{RESEARCH LIMITATIONS AND FUTURE STUDY}

The purpose behind this study was to analyze the relationship of personality traits with cyberloafing, and the greater part of the outcomes was compatible with past research. In this research, a limited sample was taken with $(\mathrm{N}=222)$ from mainly two organizations of Karachi and Islamabad. This topic is very sensitive in a competitive environment, where productivity is most important for each organization. There have been many policies developed to stop this, with different methods and techniques are applied.

Notwithstanding the privacy see toward the start of the overview, some potential members may see their contribution with a study that requests that they detail their cyberloafing as a danger to their professional stability. With the pervasive utilization of innovation in the working environment, cyberloafing is and will keep on being an essential region of research. Because of innovation developing after some time, future research needs to take measures that include all conceivable cyberloafing practices.

For a more inside investigation of practices, members could be asked how long they play out every individual conduct rather than a day by day normal and a rating scale for everything. Members could be requested to give their general position title keeping in mind the end goal to make classes of positions. By gathering all administration related, administrative, or different positions together, the consequences of examinations would be more generalizable to those 
particular occupation gatherings. The same should be possible with how long every week the member functions.

\section{Acknowledgement:}

The author(s) acknowledge the respondents cooperation and support in collection of the data.

\section{Author(s) Contribution:}

All authors have contributed equally in this research. 


\section{REFERENCES}

Aalberts, R. J., Hames, D. S., \& Thistle, P. D. (2009). Detours and frolics on the Internet: Employer liability and management control of cybertorts. Journal of Business Research, 62(12), 1335-1341. https://doi.org/10.1016/j.jbusres.2008.12.005

Anandarajan, M., Simmers, C., \& Igbaria, M. (2000). An exploratory investigation of the antecedents and impact of internet usage: An individual perspective. Behaviour \& Information Technology, 19(1), 69-85. https://doi.org/10.1080/014492900118803

Arshad, M., Aftab, M., \& Bukhari, H. (2016). The Impact of job characteristics and role stressors on cyberloafing: the case of Pakistan. International journal of scientific and research publications, 6(12), 244-251.

Askew, K., Buckner, J. E., Taing, M. U., Ilie, A., Bauer, J. A., \& Coovert, M. D. (2014). Explaining cyberloafing: The role of the theory of planned behaviour. Computers in Human Behaviour, 36, 510-519. https://doi.org/10.1016/j.chb.2014.04.006

Barrick, M. R., Mount, M. K., \& Judge, T. A. (2001). Personality and Performance at the Beginning of the New Millennium: What Do We Know and Where Do We Go Next? International Journal of Selection and Assessment, $9(1 \quad \& \quad 2), 9-30$. https://doi.org/10.1111/1468-2389.00160

Baturay, M. H., \& Toker, S. (2015). An investigation of the impact of demographics on cyberloafing from an educational setting angle. Computers in Human Behaviour, 50, 358-366. https://doi.org/10.1016/j.chb.2015.03.081

Blanchard, A. L., \& Henle, C. A. (2008). Correlates of different forms of cyberloafing: The role of norms and external locus of control. Computers in Human Behaviour, 24(3), 1067-1084. https://doi.org/10.1016/j.chb.2007.03.008

Cheng, B., Zhou, X., Guo, G., \& Yang, K. (2020). Perceived overqualification and cyberloafing: A moderated-mediation model based on equity theory. Journal of Business Ethics, 164(3), 565-577.

Colbert, A. E., Mount, M. K., Harter, J. K., Witt, L. A., \& Barrick, M. R. (2004). Interactive Effects of Personality and Perceptions of the Work Situation on Workplace Deviance. 
Journal of Applied Psychology, 89(4), 599-609. https://doi.org/10.1037/00219010.89.4.599

Costa Jr, P. T., Zonderman, A. B., \& McCrae, R. R. (1991). Personality, defense, coping, and adaptation in older adulthood.

DeShong, H. L., Grant, D. M., \& Mullins-Sweatt, S. N. (2015). Comparing models of counterproductive workplace behaviours: The Five-Factor Model and the Dark Triad. Personality and Individual Differences, 74, 55-60. https://doi.org/10.1016/j.paid.2014.10.001

DeYoung, C. G., \& Peterson, J. B. (2005). Between facets and domains: Ten aspects of the Big Five. PsycEXTRA Dataset. Published. https://doi.org/10.1037/e633942013-310

Emmons, R. A., Diener, E., \& Larsen, R. J. (1985). Choice of situations and congruence models of interactionism. Personality and Individual Differences, 6(6), 693-702. https://doi.org/10.1016/0191-8869(85)90080-7

Fazekas, C. P. (2004). 1984 is still fiction: Electronic monitoring in the workplace and U.S. privacy law. Duke Law and Technology Review, 2004, 15-15.

Glazer, S., \& Beehr, T. A. (2005). Consistency of implications of three role stressors across four countries. Journal of Organizational Behaviour, 26(5), 467-487. https://doi.org/10.1002/job.326

Griffiths, M. (2010). Internet abuse and internet addiction in the workplace. Journal of Workplace Learning, 22(7), 463 - 472. doi:10.1108/13665621011071127

Henle, C. A., \& Blanchard, A. L. (2008). The interaction of work stressors and organizational sanctions on cyberloafing. Journal of Managerial Issues, 20(3), 383-400.

Huma, Z., Hussain, S., Thurasamy, R., \& Malik, M. I. (2017). Determinants of cyberloafing: A comparative study of a public and private sector organization. Internet Research, 27(1), 97-117. doi:10.1108/into-12-2014-0317

Jamaluddin, H., Ahmad, Z., Alias, M., \& Simun, M. (2015). Personal Internet Use: The Use of Personal Mobile Devices at the Workplace. Procedia - Social and Behavioural Sciences, 172, 495-502. https://doi.org/10.1016/j.sbspro.2015.01.391

Kim, K., Del Carmen Triana, M., Chung, K., \& Oh, N. (2015). When Do Employees Cyberloaf? An Interactionist Perspective Examining Personality, Justice, and 
Empowerment. Human Resource Management, 55(6), 1014-1058. doi:10.1002/hrm.21699

Li, H., Sarathy, R., Zhang, J., \& Luo, X. (2014). Exploring the effects of organizational justice, personal ethics, and sanction on internet use policy compliance. Information Systems Journal, 24(6), 479-502. doi:10.1111/isj.12037

Lim, \& Vivien K., G. (2002). The IT way of loafing on the job: Cyberloafing, neutralizing and organizational justice. Journal of Organizational Behaviour, 23, 675-694.

Lim, V. K., \& Teo, T. S. (2005). Prevalence, perceived seriousness, justification, and regulation of cyberloafing in Singapore. Information \& Management, 42(8), 1081-1093. https://doi.org/10.1016/j.im.2004.12.002

Lim, V.K.G. (2002). The IT way of Loafing on the Job: Cyberloafing, Neutralizing and Organizational Justice. Journal of Organizational Behaviour, 23(5), 675-94. doi:10.1002/job.161

McCrae, R. R., \& Costa, P. T. (2021). Understanding persons: From Stern's personalistics to Five-Factor Theory. Personality and Individual Differences, 169, 109816. https://doi.org/10.1016/j.paid.2020.109816

McCrae, R. R., \& Costa Jr, P. T. (2008). The five-factor theory of personality.

McCrae, R. R., \& John, O. P. (2016). An introduction to the five-factor model and its applications. Journal of Personality, 60, 175-215.

Messarra, L. C., Karkoulian, S., \& McCarthy, R. (2011). To restrict or not to restrict personal internet usage on the job. Education, Business and Society: Contemporary Middle Eastern Issues, 4(4), 253-266. doi:10.1108/17537981111190042

Muhl, C. J. (2003). Workplace e-mail and Internet use: Employees and employers beware. Monthly Labor Review, 126, 36-45.

Ozler, D. E., \& Polat, G. (2012). Cyberloafing Phenomenon in Organizations: Determinants and Impacts. International Journal of eBusiness and eGovernment Studies, 4(2), 21460744 .

Panaccio, A., \& Vandenberghe, C. (2012). Five-factor model of personality and organizational commitment: The mediating role of positive and negative affective states. Journal of Vocational Behaviour, 80, 647-658. Doi: 10.1016/j.jvb.2012.03.002

Piotrowski, C. (2012). Cyberloafing: A content analysis of the emerging literature. Journal of Instructional Psychology, 39, 259-261. 
Rana, H., \& Punia, B. K. (2014). Management Mechanisms and Implications of Workplace Deviance for Green Organizational. Behaviour. International Journal of Advance Research in Computer Science and Management Studies, 2(8), 1-8.

Restubog, S. L. D., Garcia, P. R. J. M., Toledano, L. S., Amarnani, R. K., Tolentino, L. R., \& Tang, R. L. (2011). Yielding to (cyber)-temptation: Exploring the buffering role of Selfcontrol in the Relationship between Organizational Justice and Cyberloafing Behaviour in the Workplace. Journal of Research in Personality, 45(2), 247-251. Doi: 10.1016/j.jrp.2011.01.006

Ross, C., Orr, E. S., Sisic, M., Arseneault, J. M., Simmering, M. G., \& Orr, R. R. (2009). Personality and motivations associated with Facebook use. Computers in human behaviour, 25(2), 578-586.

Rousseau, V., \& Aubé, C. (2010). Social support at work and affective commitment to the organization: The moderating effect of job resource adequacy and ambient conditions. Journal of Social Psychology, 150, 321-340.

Sackett, P. R., \& DeVore, C. J. (2002). Counterproductive behaviours at work.

Sage, M. A. (2015). Cyberloafing: A study of personality factors and organizational commitment as a predictor variable of cyberloafing and perceived organization acceptance. Journal of ProQuest LLC, 5(2), 87-112.

Sai'd Ibrahim Al-Shuaibi, A., Subramaniam, C., \& Shamsudin, F. M. (2014). The Mediating Influence of Job Satisfaction on the Relationship between HR Practices and Cyberdeviance. Journal of Marketing and Management, 5(1), 105-119.

Salgado, J. F. (2002). The Big Five personality dimensions and counterproductive behaviours. International journal of selection and assessment, 10(1-2), 117-125.

Sawitri, \& Runing, H. S. (2012). Role of internet experience in moderating influence of work stressor on cyberloafing. Procedia - Social and Behavioural Sciences, 57, 320 - 324.

Seymour, L., \& Nadasen, K. (2007). Web access for IT staff: a developing world perspective on web abuse. The Electronic Library, 25(5), 543 - 557. doi:10.1108/02640470710829532

Steel, P., Schmidt, J., \& Shultz, J. (2008). Refining the relationship between personality and subjective well-being. Psychological Bulletin, 134(1), 138.

Tapia, A. H. (2006). Information technology-enabled employee deviance. In Niederman, F., \& Ferratt, T. W. (Eds.) IT workers: Human capital issues in a knowledge-based environment, (pp. 405-439). North Carolina, NC: Information Age Publishing. 
Ugrin, J. C., Pearson, J. M., \& Odom, M. D. (2008). Cyber-Slacking: Self-Control, Prior Behaviour, and the Impact of Deterrence Measures. Review of Business Information Systems (RBIS), 12(1), 75-88.

Wagner, D. T., Barnes, C. M., Lim, V. K. G., \& Ferris, D. L. (2012). Lost Sleep and Cyberloafing: Evidence from the Laboratory and a Daylight-Saving Time QuasiExperiment. Journal of Applied Psychology, 97(5), 1068-1076. Doi:10.1037/a0027557

Wilson, K., Fornasier, S., \& White, K. M. (2010). Psychological Predictors of Young Adults' Use of Social Networking Sites. Cyberpsychology, Behavior, and Social Networking, 13(2), 173-177. https://doi.org/10.1089/cyber.2009.0094 